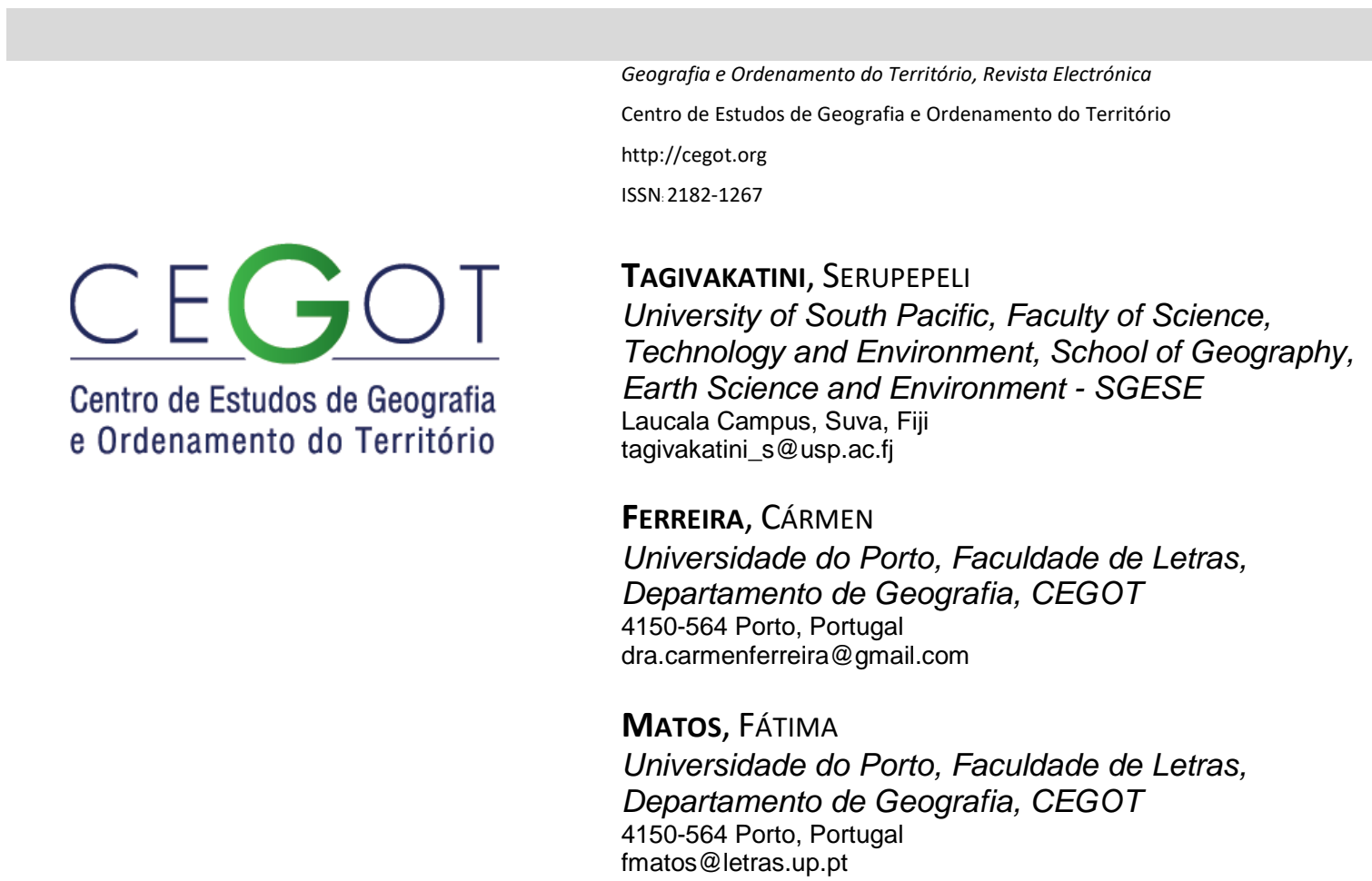

\title{
Village governance in relation to coastal resource management in Fiji: a case study of Namada and Navukailagi villages
}

\author{
A governança das aldeias e a gestão dos recursos costeiros nas Ilhas Fiji: o \\ caso de estudo das aldeias de Namada e Navukailagi
}

Referência: Tagivakatini, Serupepeli; Ferreira, Cármen; Matos, Fátima (2016). Village governance in relation to coastal resource management in Fiji: a case study of Namada and Navukailagi villages. Revista de Geografia e Ordenamento do Território (GOT), n. 10 (dezembro). Centro de Estudos de Geografia e Ordenamento do Território, p. 355-379, dx.doi.org/10.17127/got/2016.10.017

\begin{abstract}
The general aim of this research is to examine village governance structure and functions in the use, management and sustainability of coastal resources in Fiji. Traditional and contemporary systems of governance structures within the Fijian village setting play an integral role in decision-making for the well-being of every member in the community, and it is particularly important for matters relating to natural resource use. However, it is believed that poor governance is attributed to uncoordinated efforts of the dual governance system that continues to give rise to the many problems encountered in Fijian villages.
\end{abstract}

Keywords: Governance, Traditional Institutions, Coastal Resource Management, Namada Village, Navukailagi Village, Fiji Islands.

\section{RESUMO}

O objetivo geral desta investigação é examinar a estrutura e funções de governança nas aldeias, relativamente à utilização, gestão e sustentabilidade dos recursos costeiros nas ilhas Fiji. Os sistemas 
tradicionais e contemporâneos de estruturas de governança dentro do ambiente da aldeia fijiana, desempenham um papel fundamental na tomada de decisão para o bem-estar de todos os membros da comunidade e é, particularmente, importante para as questões relativas à utilização dos recursos naturais. No entanto, acredita-se que a má governação é atribuída aos esforços descoordenados deste sistema de dupla governança que continua a dar origem a muitos problemas encontrados nas aldeias das ilhas Fiji.

Palavras-chave: Governança, Instituições Tradicionais, Gestão dos Recursos Costeiros, Namada Village, Navukailagi Village, Ilhas Fiji.

\section{Introduction}

Governance has become a 'hot' topic as evidence mounts on the critical role it plays in determining societal well being (Graham, et al., 2003). The former Secretary General of the United Nations, Kofi Anan, reflects a growing consensus when he states that 'good governance' is perhaps the single most important factor in eradicating poverty and promoting development (Sanday, 2003). The effect of good governance has also been echoed to have a positive correlation with institution effectiveness (Kaufmann et al., 2009); and Lockwood (2010) echoes that establishing and maintaining good governance across the diversity of ownership and responsibility arrangements is critical for future effectiveness and acceptability of natural resources. Pressure on our natural resources has mounted and as Chhotray and Stoker (2009) noted this has been triggered by forces of globalization and democratization; and the implications have increased the pressure on established systems on collective decision making and thus have brought forth new forms of governance.

The Pacific Islands have little prominence in the good governance and resource management literature or, when they have appeared, have been seen as small environments and communities inevitably caught up in the wider impacts of global environment change (Pernetta and Hughes, 1990).

The research looked at governance as an umbrella concept where its key components could be taken down to the lowest levels of society (e.g. the village) to strengthen institutions processes. At village level the dual systems of governance had been examined. Through the use of good governance principles, the good and bad governance practices were identified in their roles and functions. Governance solutions and recommendations were then being put forward as a way to strengthen institutions and decision-making processes. This was proposed to have an effective impact on natural resource management.

To coin an appropriate definition of "village governance" is difficult. Taking in consideration in this context the communal settings, traditions and cultures that exists in Fijian villages it would be ideal to incorporate a few used definitions of governance that are appropriate. One that is used by the UNDP (2005) states governance as: 
"complex mechanisms, processes, relationships and institutions through which institutions and groups articulate their interests, exercise their rights and obligations and mediate their differences." (p.3)

Another definition that closely relates to the UNDP version is one by Chhotray and Stoker (2009) where they state governance as:

"about the rules of collective decision-making in settings where there is a plurality of actors or organizations and where no formal control systems can dictate the terms of relationship between these actors and organizations" (p.3).

Decision making institutions than needs a system of governance devised to consolidate institutions that make important decisions for the well being of the people. Governance is a very critical process to strengthen institutional arrangements and structures, and how best people manage their resources. In the case of protected area governance Graham, et al. (2003) states that it concerns to:

"the structures, processes and traditions that determines how power and responsibilities are exercised, how decisions are taken and how stakeholders have their say" (p.1).

Institutions emerge to regulate a reciprocated way of communitarian life, as Lijphart (1984) states their task is to constrain individual behavior in accordance with the requirement of community welfare. Community differs depending on their geographical settings; some are in very urbanized areas, and others in rural isolated areas. Traditional societies are usually associated with the latter, mostly which, still value customs and traditions passed down from older generations. Traditional or indigenous institutions is according to "the structures and units of organization in a community and encompass norms, values, beliefs and vision that guide social interaction"(Cocks, 2006, p.188).

In their work Kendi and Guri (2007) agree that traditional institutions shape the local organization, while the leadership structures within the community and their functional roles ensure compliance with rules, norms and beliefs on the part of the populace. Further, Kendi and Guri added that in rural communities traditional institutions assist to achieve improvements in the socio-economic conditions of its members. Poorly functioning public sector institutions and weak governance are major constraints to growth and resource management in many developing countries (The World Bank, 2000).

On the contrary good governance as a driver for effectiveness sprung up as a result of the many gaps and weaknesses that were prevalent in institutions of the past. Good governance was seen as a probable way forward to address these flaws. There needs to be checks and balances on its use through measures and performance indicators. Good governance is a subset of governance, where public resources and problems are managed effectively, efficiently and in response to critical needs of society (Graham et al., 2003). It constitutes principles that are participatory, transparent, accountable, equitable, and promotes the rule of law fairly (UNESCAP, 2007). Good governance ensures that the voices of the poorest and the most vulnerable are heard in decision-making over the allocation of development resources, and that political, social and economic priorities are based on broad consensus among the three stakeholders, the state, private sectors and civil society (UNDP, 2005). 
In Fijian villages like Navukailagi and Namada, the existence of a dual system of contemporary (Bose Vakoro) and traditional (Bose Vanua) systems has created conflicts on the decision-making process, roles and responsibilities of traditional and contemporary village institutions thus affecting governance of coastal resources.

The general aim of this research is to examine village governance structure and functions in the use, management and sustainability of coastal resources in Fiji. The aim was centered on the following objectives:

i) To examine governance, governance structures, and practices at the local village level.

ii) To critically analyze the governance practices of traditional and contemporary institutions so as to identify issues of bad governance' in a village setting and;

iii) To offer solutions and make recommendations as workable practices that can enhance natural resource management at village level.

The issues of poor governance in our Fijian villages stemming from poor decision-making process that have continued to be highlighted as contributing to poor resource management practices. Strategies and measures to counter the decline and collapse of coastal marine resources have become the focus of national and concerned institutions in Fiji, which include the work of Institute of Applied Sciences (IAS), Fiji Locally Marine Managed Areas (FLMMA) and Integrated Coastal Management (ICM).

With the on-going efforts to finding workable strategies, this research hoped to contribute to the little literature on resource governance particularly for coastal villages in Fiji.

Village governance is a vital area for research as it would effectively address the gaps that exist on how 'i qoliqoli' (traditional fishing grounds) owners manage their natural resources. It would ensure the empowerment and protection of village institutions, resource rights, resource rules compliance and enforcement of resource users. In addition to this, cultural values and beliefs regarding coastal resources, leadership and resource conflict between users of marine resources within a village setting will also be addressed.

\section{Study Area and Methods}

The selected study sites are Namada Village in Nadroga, on the mainland of Viti Levu and Navukailagi Village on the island of Gau in Republic of Fiji Islands (Fig. 1).

Qualitative research method was used to collect data. The approach allowed for the 'human' side of issues faced. Qualitative research based in key informants interviews and focus groups were used as the researcher sought to understand issues from the perspectives of the local people. These methods according to Glesne and Peshkin (1992) are also effective as it could identify intangible factors, such as social norms, gender roles, ethnicity and religion whose role in research issues are not readily apparent. Data was also collected from workshops and trainings particularly related to 
village governance and natural resource management in various Fijian villages including the two case study areas.

Data collection for this research was conducted in the two villages of Namada and Navukailagi as shown in Fig. 1. The two villages have been pilot sites with Marine Protected Area (MPA) establishments since the early 2000.

Namada has a total population of 147 individuals with 87 males $(60 \%)$ and 60 females $(40 \%)$ in terms of gender. There are 50 individuals (34\%) in the age groups of 21-60 years old and only 14 (10\%) with above 60 yrs. The remaining $83(56 \%)$ of the population are the young below the age of 19 years.

The village of Navukailagi has a total population of 104 individuals, whereby $58(56 \%)$ are males and $46(44 \%)$ females. There are only $13(13 \%)$ in the elderly age group of above 60 years, $44(43 \%)$ in the age groups between $20-60$ years and 47 individuals (44\%) below 19 years of age.

The questionnaires used for the interviews have 48 questions for the both questionnaires structured and unstructured that was divided into 5 broad parts (A - E). Part A is constituted by personal questions related to interviewee status and general background. Part $B$ by questions relative to the Institution or Committee that the interviewees belonged, part $\mathrm{C}$ was made up by questions on interviewee's perception on the functions and operations of 'Chief's Council' and 'Village Council' that are the two decision making institutions. Part $D$ asks questions about work of natural resource management which is overseen and undertaken by the 'Village Development Committee' and part $\mathrm{E}$ is related to effectiveness and participation of stakeholders from outside village towards natural resource management.

The 68 interviewees from both villages (38 for Namada and 30 for Navukailagi) were guided in the discussion to cover important areas and add to the topic depending on their interest and expertise. Focus was on traditional institutions, leadership, resource rights and rules, compliance and enforcement, cultural values and their beliefs regarding marine resources, resource conflicts, changes in management regimes and strategies over the past years.

The key informants' interview technique was used to gather general data from both villages. Key informant refers to the person with whom an interview about a particular organization, social program, problem, or interest group is conducted (Mckenna et al., 2011). There were a total of 19 key informants from both villages. These selected community members (chief, clan leader, village spokesperson, church minister, and heads or leaders from village men and women's groups, also men's and women's church groups, development committee, youth and church youth groups) were able to reveal valuable supplementary information on issues pertaining to their institutions and committees, changes in their community, perceptions of change in governance and their views on the operation of other groups. This method allowed the collection of information through direct observations, informal conversations and discussions with key informants. It also provided participants with a chance to express views and opinions that may not necessarily be envisioned.

The focus groups interviews, it's a method that "at the broadest possible level, are collective conversations or group interviews" (Kamberelis and Dimitrias, 2005). Focus group interviews were mainly made up of 2 or 3 committee's members of the chief's council, village council, village women, 
village men, church women, church men, village youth, church youth, and development committee. There were about three people chosen from each group. The main reason for the use of this method was that these groups provide essential additional information on tightly outlined, harder-to-access, subjects that will come up as essential and important during the previous observations. The information gathered was deduced as their general perception of village and resource governance.

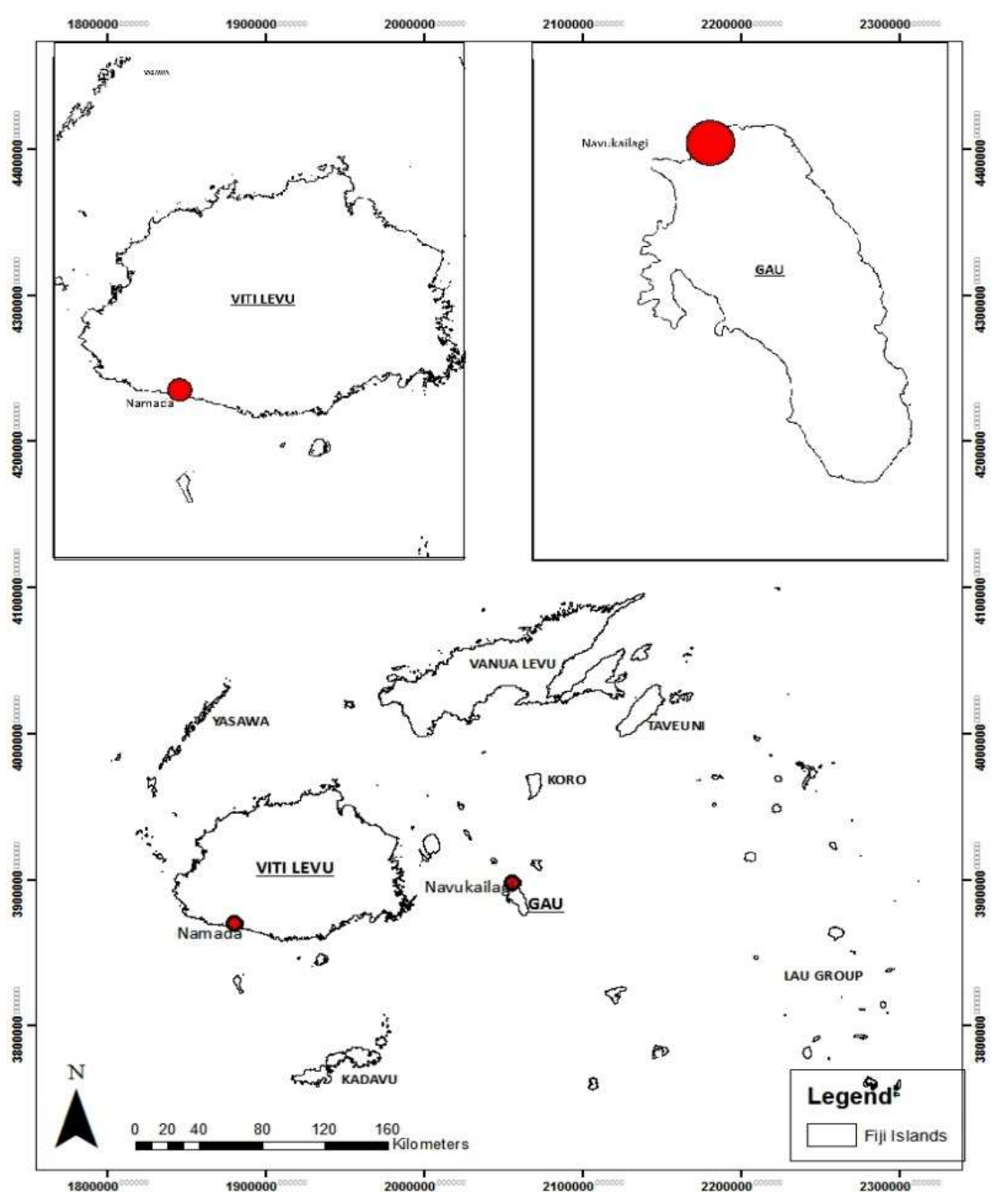

Figure 1 - Geographical location of the Study Area in relation to the Fiji Island

A 'talanoa' ${ }^{1}$ approach (Otsuka, 2006) was also used but guided by the use of questionnaire. This approach was found to be most suited when approaching villagers, as it puts them at ease without appearing to be prying.

Other observations and records of data were gathered in our participations at meetings and workshops in the two villages.

The SPSS software was used to analyze data and tabulated findings.

${ }^{1}$ A conversation, a talk, an exchange of ideas or thinking, whether formal or informal (Vaioleti, 2006). 


\section{Results and Discussion}

\subsection{Fijian Village Social Structure}

The social structure in Figure 2 shows that what are common in both villages were two major decision-making institutions: the Village Council (Bose Vakoro), contemporary and the Chiefs Council (Bose Vanua), the traditional. An overview of what constitutes these two institutions and their memberships are summarized in Table 1.

The Chiefs Council or Bose Vanua primarily is made up of the chief district, clan and sub-clan leaders and is solely a traditional institution. Under this are the extended families and their individual family units as shown on the right side of the social structure in Figure 2. The Village Council has under its jurisdiction the Church (Lotu) which plays a significant and influential role in the spiritual well-being of the people, empowering them in their decision-making. Under the umbrella of the Church (Lotu) are three of its working groups namely the Men's Church, Women's Church, and Church Youth Groups. The village Council also shows seven other committees or groups directly under it; the Village Men's Group, the Village Women's Group, the Village Youth Group, and the Development or Natural Resource Management Committee. Together these groups form part of the quorum for discussions and decision-making issues of in the Village Council.

\begin{tabular}{|c|c|c|c|}
\hline TYPE & INSTITUTION & GROUP & MEMBERSHIP \\
\hline \multirow{9}{*}{ Contemporary } & \multirow{9}{*}{$\begin{array}{l}\text { VILLAGE COUNCIL } \\
\text { (Bose Vakoro) }\end{array}$} & Village Council Meeting & All village members \\
\hline & & $\begin{array}{l}\text { Village Men's Group } \\
\text { (Soqosoqo ni Turaga) }\end{array}$ & $\begin{array}{l}\text { All village men (usually } \\
\text { fathers and older men) }\end{array}$ \\
\hline & & $\begin{array}{l}\text { Village Women's Group } \\
\text { (Soqosoqo ni Marama) }\end{array}$ & $\begin{array}{l}\text { All village women } \\
\text { (mothers and older } \\
\text { women folks) }\end{array}$ \\
\hline & & $\begin{array}{l}\text { Youth Group (Soqosoqo } \\
\text { ni Tabagone) }\end{array}$ & $\begin{array}{l}\text { All youths usually above } \\
18-26 \text { years }\end{array}$ \\
\hline & & $\begin{array}{l}\text { Development Committee } \\
\text { (Soqosoqo } \\
\text { Veivakatorocaketaki) }\end{array}$ & $\begin{array}{l}\text { Representatives chosen } \\
\text { from Village Council }\end{array}$ \\
\hline & & CHURCH (Lotu) & \\
\hline & & $\begin{array}{l}\text { Men's Church Group } \\
\text { (Soqosoqo ni Lotu ni } \\
\text { Turaga) }\end{array}$ & $\begin{array}{l}\text { Men of the Methodist } \\
\text { congregation }\end{array}$ \\
\hline & & $\begin{array}{l}\text { Women's Church Group } \\
\text { (Soqosoqo ni Lotu ni } \\
\text { Marama) }\end{array}$ & $\begin{array}{l}\text { Women of } \\
\text { Methodist } \\
\text { Congregation }\end{array}$ \\
\hline & & $\begin{array}{l}\text { Youth Church Group } \\
\text { (Mataveitokani) }\end{array}$ & $\begin{array}{l}\text { Youths of the } \\
\text { Methodist } \\
\text { Congregation }\end{array}$ \\
\hline Traditional & $\begin{array}{l}\text { CHIEF"S COUNCIL } \\
\text { (Bose Vanua) }\end{array}$ & & $\begin{array}{l}\text { Chiefs and clan leaders } \\
\text { only }\end{array}$ \\
\hline
\end{tabular}

Table 1 - Overview of contemporary and traditional institutions in Navukailagi and Namada villages Source: Tagivakatini, 2013, p. 61 

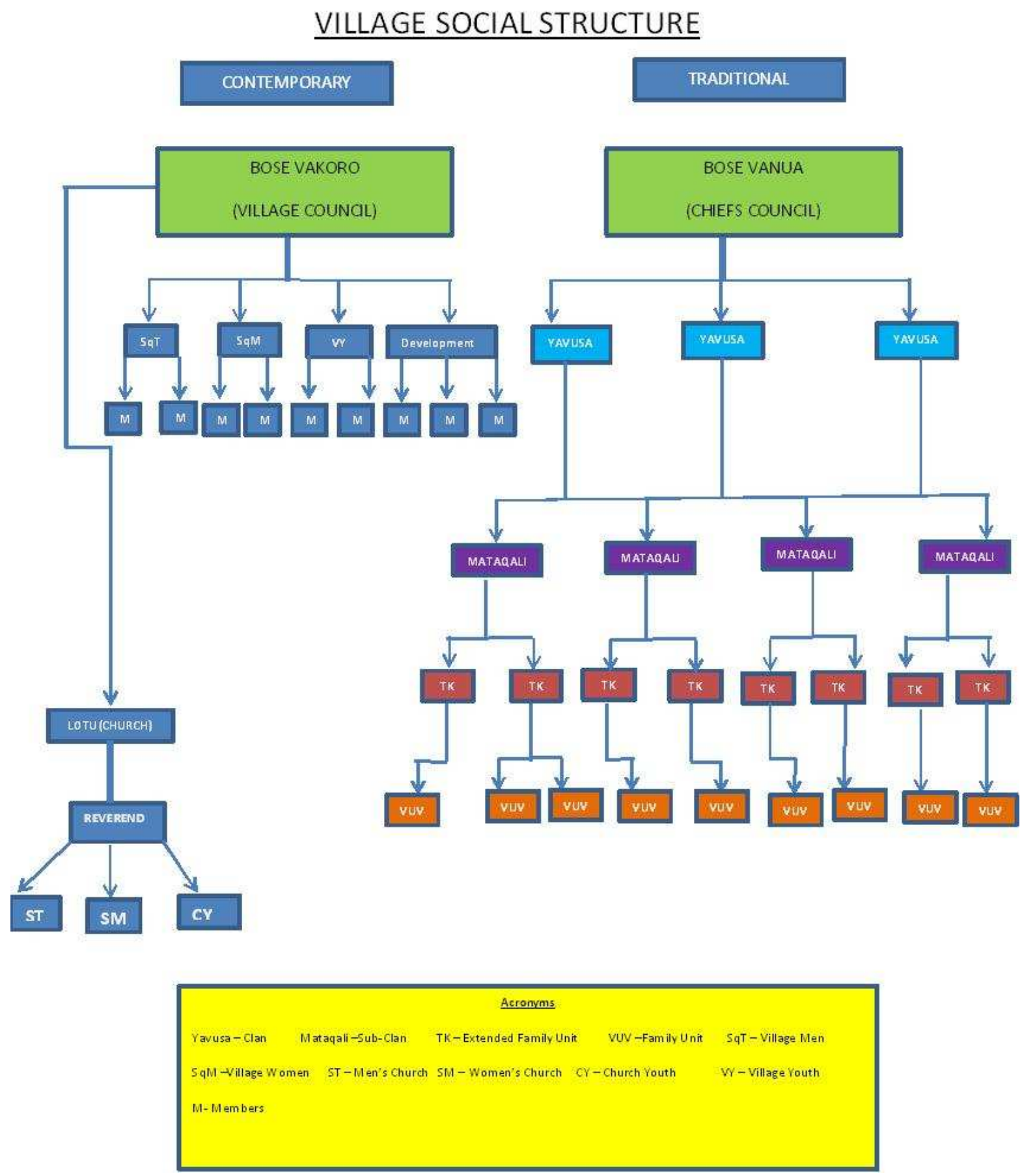

Figure 2 - Village Social Structure common in both villages (Tagivakatini, 2013, p. 60)

\subsection{Governance Practices in Fijian Villages}

\section{a) Traditional institutions - Chiefs Council (Bose Vanua)}

The Chiefs' Council is the traditional Fijian institution which according to 25 (37\%) respondents of both villages stated that it "ensures maintenance of traditional and cultural values in the village and 
district". A further 23 (33\%) respondents stated that it "ensured those who rightly deserved to be part of it make decision for the people" and $16(24 \%)$ others echoed this institution to be one that "advises the most traditional and corrective measures to be undertaken during conflict" situations (Table 2). In Navukailagi 4 (6\%) respondents added to "seek advice from the Native Lands Commission and the Fijian Affairs Board on land and leadership matters".

\begin{tabular}{|c|c|c|c|c|c|c|}
\hline \multicolumn{7}{|c|}{ Village ${ }^{\star}$ What is the role and function of the Chiefs Council? Crosstabulation } \\
\hline & & \multicolumn{4}{|c|}{ What is the role and function of the Chiefs Council? } & \multirow[b]{2}{*}{ Total } \\
\hline & & $\begin{array}{l}\text { To ensure } \\
\text { maintenance } \\
\text { of traditional } \\
\text { and cultural } \\
\text { values in } \\
\text { village and } \\
\text { district }\end{array}$ & $\begin{array}{c}\text { To ensure } \\
\text { that those } \\
\text { who should } \\
\text { rightly } \\
\text { deserve to be } \\
\text { part of it and } \\
\text { make } \\
\text { decisions be } \\
\text { there for the } \\
\text { people }\end{array}$ & $\begin{array}{l}\text { It advises of } \\
\text { most } \\
\text { traditional } \\
\text { corrective } \\
\text { measures to } \\
\text { be } \\
\text { undertaken } \\
\text { during } \\
\text { conflicts }\end{array}$ & $\begin{array}{l}\text { Seeks advise } \\
\text { from Native } \\
\text { Lands } \\
\text { Commission } \\
\text { and Fijian } \\
\text { Affairs Board } \\
\text { on land and } \\
\text { leadership } \\
\text { matters }\end{array}$ & \\
\hline \multirow[t]{2}{*}{ Village } & Namada & 18 & 11 & 9 & 0 & 38 \\
\hline & Navukailagi & 7 & 12 & 7 & 4 & 30 \\
\hline Total & & 25 & 23 & 16 & 4 & 68 \\
\hline
\end{tabular}

Table 2 - The Chief's Council Role and Function

According interview responses from both villagers Table 3, 32 (47\%) respondents had answered that the chiefs Council is made up of "chief of the district" and 36 (53\%) answered "clan and sub-clan leaders".

Village * Who are members of the Chiefs Council? Crosstabulation

\begin{tabular}{|c|c|c|c|c|}
\hline & \multicolumn{2}{|c|}{ Who are members of the Chiefs Council? } & \multirow[b]{2}{*}{ Tota } \\
\hline & & Chief of the district & Clan and Sub-Clan leaders & \\
\hline \multirow[t]{2}{*}{ Village } & Namada & 22 & 16 & 38 \\
\hline & Navukailagi & 10 & 20 & 30 \\
\hline Total & & 32 & 36 & 68 \\
\hline
\end{tabular}

Table 3 - Chief's Council Membership

\section{b) Contemporary institutions - Village council (Bose Vakoro)}

The village council is the contemporary institution common in both villages which according to 29 (43\%) respondents from both villages stated its role and function was to communicate important information from the Government through the Fijian Affairs Board to provide assistance or any other development plans from 'outside' to the village (Table 4). A total of $11(16 \%)$ respondents stated that this institution provided support to the Chiefs and District Councils by implementing all their planned activities. Another 9 (13\%) respondents from both villages stated that the Village Council existed to ensure that village by-laws were protected and followed by members and that peace and 
good-will prevailed all the time; $4(6 \%)$ respondents stated that it provided a forum where issues of conflicts could be raised. Another $9(13 \%)$ responded that the village council was overseen by the village spokesperson and it looked after all general activities like village health, hygiene and general cleanliness (Table 4). There were $6(9 \%)$ respondents that also stated that the village council discusses and either approves or disapproves important matters like new Christian faiths and denominations wanting establishment in the village.

\begin{tabular}{|c|c|c|c|c|c|c|c|c|}
\hline \multicolumn{9}{|c|}{ Village * What is the roles and functions of the Village Council? Crosstabulation } \\
\hline \multicolumn{9}{|l|}{ Count } \\
\hline & & \multicolumn{6}{|c|}{ What is the roles and functions of the Village Council? } & \multirow[b]{2}{*}{ Total } \\
\hline & & $\begin{array}{c}\text { It } \\
\text { communicate } \\
\text { s important } \\
\text { information } \\
\text { from } \\
\text { government } \\
\text { on assistance } \\
\text { and other } \\
\text { development } \\
\text { plans to } \\
\text { village. } \\
\end{array}$ & $\begin{array}{l}\text { It ooks after } \\
\text { all general } \\
\text { activities like } \\
\text { village health } \\
\text { and hygiene } \\
\text { and general } \\
\text { cleanliness. }\end{array}$ & $\begin{array}{c}\text { It also } \\
\text { approves or } \\
\text { disapproves } \\
\text { of new faiths } \\
\text { or } \\
\text { denomination } \\
\text { s wanting } \\
\text { establishmen } \\
\text { t in the village } \\
\end{array}$ & $\begin{array}{l}\text { It provides } \\
\text { support to the } \\
\text { Chiefs } \\
\text { Council and } \\
\text { district } \\
\text { Council by } \\
\text { implementing } \\
\text { out all its } \\
\text { planned } \\
\text { activities } \\
\end{array}$ & $\begin{array}{l}\text { It is the forum } \\
\text { where issues } \\
\text { of conflicts } \\
\text { can be raised } \\
\text { and it } \\
\text { provides } \\
\text { advice and } \\
\text { possible } \\
\text { solutions to } \\
\text { conflicts } \\
\end{array}$ & $\begin{array}{l}\text { It ensures that } \\
\text { village by- } \\
\text { laws are } \\
\text { protected and } \\
\text { followed by } \\
\text { members and } \\
\text { that peace } \\
\text { and goodwill } \\
\text { prevail all } \\
\text { times. } \\
\end{array}$ & \\
\hline \multirow[t]{2}{*}{ Village } & Namada & 10 & 7 & 5 & \begin{tabular}{|l|}
7 \\
\end{tabular} & 2 & \begin{tabular}{|l|}
7 \\
\end{tabular} & 38 \\
\hline & Navukailagi & 19 & 2 & 1 & 4 & 2 & 2 & 30 \\
\hline Total & & 29 & 9 & 6 & 11 & 4 & 9 & 68 \\
\hline
\end{tabular}

Table 4 - Role and Function of Village Council

According to Table 5, 38 (56\%) respondents from both villages said that Village Council Membership are chosen from representatives of the different clans, sub-clans and other committees in the village and that they were led by the village spokesperson. Another $30(44 \%)$ responded that the Village Council was made up of all village members presently residing with ages of above 18 years who may actively participate in the forum.

\begin{tabular}{|c|c|c|c|c|}
\hline \multicolumn{5}{|c|}{ Village * Who are members of the Village Council? Crosstabulation } \\
\hline & & \multicolumn{2}{|c|}{ Who are members of the Village Council? } & \multirow[b]{2}{*}{ Total } \\
\hline & & $\begin{array}{l}\text { They are chosen reps } \\
\text { from each clan, sub- } \\
\text { clan and other } \\
\text { committees in the } \\
\text { village, led by the } \\
\text { Village spokesperson }\end{array}$ & $\begin{array}{c}\text { Village Council } \\
\text { members are made } \\
\text { up all members above } \\
18 \text { years residing in } \\
\text { the village }\end{array}$ & \\
\hline Village & Namada & 16 & 22 & 38 \\
\hline & Navukailagi & 22 & 8 & 30 \\
\hline Total & & 38 & 30 & 68 \\
\hline
\end{tabular}

Table 5 - Village Council Membership

Under the Village Council are two other groups and committees, but two main ones that played an influential role were the Church and the Development Committee (responsible for Natural Resource Management, NRM).

The Church or Lotu in both villages represents the Methodist denomination that plays a pivotal and influential role in decision making. It sets a code of spiritual practices and have procedures bounded by written constitution of its head body the Methodist Church in Fiji, that all its followers are obliged to follow. According to Table 6, the 19 church members interviewed from the two villages describes that there are three main groups of the church that villagers are obligated to become part depending on their gender and age groupings. Youths automatically become part of the Church 
Youth, and all village men and women belonging automatically to the respective Methodist denomination and participated in the activities of their groups.

\begin{tabular}{|c|c|c|c|c|c|}
\hline \multicolumn{6}{|l|}{ Count } \\
\hline & & \multicolumn{3}{|c|}{ Who are its members? } & \multirow[b]{2}{*}{ Total } \\
\hline & & $\begin{array}{l}\text { (CHURCH } \\
\text { YOUTH) } \\
\text { Youths of } \\
\text { Methodist } \\
\text { congregation } \\
\text { only }\end{array}$ & $\begin{array}{c}\text { (MENS } \\
\text { CHURCH } \\
\text { GROUP) Men } \\
\text { in the } \\
\text { Methodist } \\
\text { congregation } \\
\text { only } \\
\end{array}$ & $\begin{array}{c}\text { (WOMENS } \\
\text { CHURCH } \\
\text { GROUP) } \\
\text { Women in the } \\
\text { Methodist } \\
\text { Congregation } \\
\text { only }\end{array}$ & \\
\hline \multirow{3}{*}{$\begin{array}{l}\text { Village } \\
\text { Total }\end{array}$} & Namada & 3 & 1 & 4 & 8 \\
\hline & Navukailagi & 3 & 4 & 3 & 11 \\
\hline & & 6 & 5 & 7 & 19 \\
\hline
\end{tabular}

Table 6 - Church Group Membership

The Development Committee, under the Village Council, is tasked with looking after natural resources management projects like the Marine Protected Area (MPA) initiative. Table 7 showed responses from both villages on this committee.

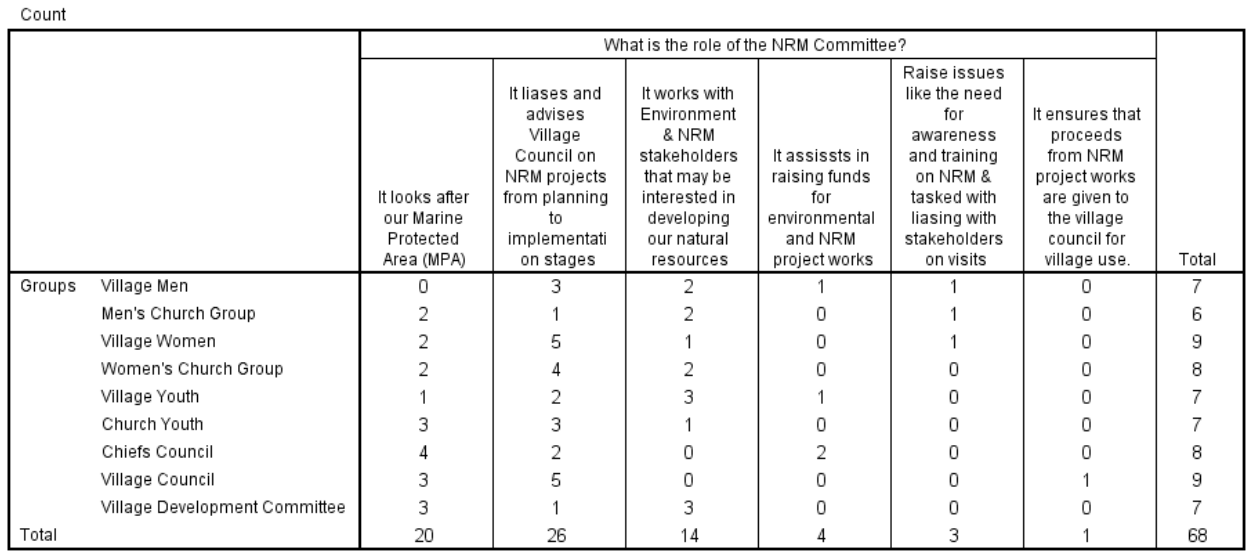

Table 7 - Role of Development Committee (responsible for NRM work)

\subsection{Examining village functions - good governance principles and performance indicators}

The principle of good governance and some performance indicators outlined in Table 8 were used to gauge and assess the performance of the institutions and their affiliated committees and groups.

\section{a) Membership of institution/committees and Representation of Wider Community}

In Table 9, related with Members representative of the wider community, there were 33 (49\%) respondents that represented the chiefs council, village council including the women's church and village men groups that stated that membership of institutions was 'not inclusive of all'. There were $7(10 \%)$ responses that accounted for 'only a few are included'. According to $18(26 \%)$ others respondents 'some are included' and another 10 (15\%) echoed that 'all are included' as far as members representative of the wider community' is concerned. 


\begin{tabular}{|c|c|}
\hline INDICATOR & PERFORMANCE MEASURES \\
\hline Membership & Committee representative of a wide community (inclusive of youth, women, etc.) \\
\hline \multirow[t]{2}{*}{ Meetings } & Number of meetings held \\
\hline & Number of people attending meetings \\
\hline \multirow{3}{*}{$\begin{array}{l}\text { Documentation } \\
\text { and Reporting }\end{array}$} & Documentation of meetings and disseminated to all members (transparent) \\
\hline & Financial records and Budget available; disseminated to all members (transparent) \\
\hline & Safe keeping of documents \\
\hline \multirow[t]{2}{*}{ Roles and Functions } & Clearly defined to all members \\
\hline & Representative of the needs of all members \\
\hline \multirow[t]{4}{*}{ Management Action Plans } & Management Action Plan (MAP) exist \\
\hline & Participation within in formulation of MAP \\
\hline & Collaboration of outsiders in MPA formulation \\
\hline & Completion of tasks according to timeframes in MAP \\
\hline $\begin{array}{l}\text { Inventory of resources, equipment and } \\
\text { facilities }\end{array}$ & List of resources, equipment and facilities \\
\hline \multirow[t]{5}{*}{ Rules and regulations } & Are there rules \& regulations and are members aware of them \\
\hline & Socially acceptable to all \\
\hline & Who makes rules \& regulations \\
\hline & Enforcing of rules \& regulations and Reports \\
\hline & Violation and punishment \\
\hline \multirow{2}{*}{$\begin{array}{lll}\begin{array}{l}\text { Decision-making } \\
\text { procedures) }\end{array} & \text { (Processes } \quad \& \\
\end{array}$} & Clearly defined \\
\hline & Conflict resolutions \\
\hline \multirow[t]{4}{*}{ Leadership } & Degree of influence \\
\hline & Traditionally installed \& recognized \\
\hline & Attendance of Leadership \& Management trainings \\
\hline & Accountability to subordinates \\
\hline \multirow{5}{*}{$\begin{array}{l}\text { Connectivity - Work of Natural } \\
\text { Resource Management work } \text { (e.g. } \\
\text { Marine Protected Area -Project) }\end{array}$} & Process and procedures of establishment \\
\hline & Rules clearly defined and socially acceptable \\
\hline & Compliance with and enforcement with resource use rules \\
\hline & Participation of outside stakeholders \\
\hline & Training and awareness \\
\hline
\end{tabular}

Table 8 - Governance indicators used to gauge village function performance

Source: Tagivakatini, 2013, p. 66

Groups * Is that comitee representative of a wide community Crosstabulation

Count

\begin{tabular}{|c|c|c|c|c|c|c|}
\hline & & \multicolumn{4}{|c|}{ Is that comitee representative of a wide community } & \multirow[b]{2}{*}{ Total } \\
\hline & & $\begin{array}{c}\text { Not inclusive } \\
\text { at all }\end{array}$ & $\begin{array}{c}\text { Only a few are } \\
\text { included }\end{array}$ & $\begin{array}{c}\text { Some are } \\
\text { included }\end{array}$ & $\begin{array}{c}\text { All are } \\
\text { included }\end{array}$ & \\
\hline \multirow[t]{9}{*}{ Groups } & Village Men & 4 & 0 & 0 & 3 & 7 \\
\hline & Men's Church Group & 1 & 0 & 1 & 4 & 6 \\
\hline & Village Women & 1 & 1 & 5 & 2 & 9 \\
\hline & Women's Church Group & 8 & 0 & 0 & 0 & 8 \\
\hline & Village Youth & 0 & 0 & 7 & 0 & 7 \\
\hline & Church Youth & 0 & 2 & 4 & 1 & 7 \\
\hline & Chiefs Council & 8 & 0 & 0 & 0 & 8 \\
\hline & Village Council & 6 & 2 & 1 & 0 & 9 \\
\hline & Village Development Committee & 5 & 2 & 0 & 0 & 7 \\
\hline Total & & 33 & 7 & 18 & 10 & 68 \\
\hline
\end{tabular}

Table 9 - Committee - Members representative of the wider community 


\section{b) Meetings}

Having regular meetings with number of people in attendance and meeting minutes disseminated to all members are important indicators for institution performance. Table 10 show whilst the Village Council and its affiliated groups together with the Church groups had regular meetings. All 68 (100\%) respondents from both villages agreed that meetings were held however there were different views on the question of 'how often were meetings held'. For example, the Chief's Council groups from both combined villages responded that their meeting either occurred most of the time, sometimes only, either quarterly, half yearly or yearly (Table 10).

Responses of both villages on meeting attendance on the two main decision-making bodies are shown on Table 11 and 12 so as to make comparisons. A large number of 32 (47\%) of all interviewed responded that 'less than 25\%' attend meetings for chief's council, that is if it was held either monthly or yearly. It was different for attendance for village council meetings which 24 (35\%) and 25 (37\%) that accounted for 'about 75\%-100\%' and 'about 50\%' attendance monthly. Generally from the total response it can be deduced that meeting were happening either most or all the time.

\begin{tabular}{|c|c|c|c|c|c|c|c|}
\hline \multicolumn{8}{|c|}{ Groups * Number of meetings held Crosstabulation } \\
\hline & & \multicolumn{5}{|c|}{ Number of meetings held } & \multirow[b]{2}{*}{ Total } \\
\hline & & $\begin{array}{l}\text { All the time } \\
\text { (qtrly/half } \\
\text { yrly/yrly) }\end{array}$ & $\begin{array}{c}\text { Most of the } \\
\text { time (qtrly/half } \\
\text { yrly/yrly) }\end{array}$ & $\begin{array}{c}\text { Sometimes } \\
\text { only (qtrly/half } \\
\text { yrly/yrly) }\end{array}$ & $\begin{array}{c}\text { A few } \\
\text { meetings } \\
\text { held (qtrly } \\
\text { yrly/yrly) }\end{array}$ & $\begin{array}{c}\text { No meetings } \\
\text { held at all } \\
\text { (qtrly/half } \\
\text { yrly/yrly) }\end{array}$ & \\
\hline \multirow[t]{9}{*}{ Groups } & Village Men & 3 & 1 & 2 & 0 & 1 & 7 \\
\hline & Men's Church Group & 4 & 2 & 0 & 0 & 0 & 6 \\
\hline & Village Women & 4 & 4 & 1 & 0 & 0 & 9 \\
\hline & Women's Church Group & 3 & 4 & 1 & 0 & 0 & 8 \\
\hline & Village Youth & 3 & 0 & 0 & 4 & 0 & 7 \\
\hline & Church Youth & 2 & 3 & 2 & 0 & 0 & 7 \\
\hline & Chiefs Council & 0 & 3 & 1 & 2 & 2 & 8 \\
\hline & Village Council & 4 & 5 & 0 & 0 & 0 & 9 \\
\hline & Village Development Committee & 1 & 3 & 1 & 2 & 0 & 7 \\
\hline Total & & 24 & 25 & 8 & 8 & 3 & 68 \\
\hline
\end{tabular}

Table 10 - Number of meetings held for Institutions and Groups

\begin{tabular}{|c|c|c|c|c|c|c|c|}
\hline & & \multicolumn{5}{|c|}{ Number of members attending Chiefs Council meetings? } & \multirow[b]{2}{*}{ Total } \\
\hline & & $\begin{array}{c}\text { About } 75 \% \text { - } \\
100 \% \text { every } \\
\text { meeting } \\
\text { (monthly, etc) }\end{array}$ & $\begin{array}{c}\text { About } 50 \% \text { - } \\
75 \% \text { every } \\
\text { meeting } \\
\text { (monthly, etc) }\end{array}$ & $\begin{array}{l}\text { About } 50 \% \\
\text { every meeting } \\
\text { (monthly, etc) }\end{array}$ & $\begin{array}{l}\text { About } 25 \% \text { - } \\
50 \% \text { every } \\
\text { meeting } \\
\text { (monthly, etc) }\end{array}$ & $\begin{array}{l}\text { Less than } \\
25 \% \text { every } \\
\text { meeting } \\
\text { (monthly, etc) }\end{array}$ & \\
\hline \multirow[t]{9}{*}{ Groups } & Village Men & 0 & 4 & 0 & 0 & 3 & 7 \\
\hline & Men's Church Group & 0 & 0 & 2 & 0 & 4 & 6 \\
\hline & Village Women & 1 & 4 & 1 & 0 & 3 & 9 \\
\hline & Women's Church Group & 2 & 2 & 1 & 0 & 3 & 8 \\
\hline & Village Youth & 0 & 2 & 2 & 0 & 3 & 7 \\
\hline & Church Youth & 0 & 2 & 1 & 0 & 4 & 7 \\
\hline & Chiefs Council & 0 & 4 & 1 & 0 & 3 & 8 \\
\hline & Village Council & 0 & 0 & 4 & 1 & 4 & 9 \\
\hline & Village Development Committee & 0 & 0 & 0 & 2 & 5 & 7 \\
\hline Total & & 3 & 18 & 12 & 3 & 32 & 68 \\
\hline
\end{tabular}

Table 11 - Number of members attending Chief's Council meetings 


\begin{tabular}{|c|c|c|c|c|c|c|}
\hline & & \multicolumn{4}{|c|}{ How many people attend Village Council meetings } & \multirow[b]{2}{*}{ Total } \\
\hline & & $\begin{array}{c}\text { About } 75 \% \\
-100 \% \text { every } \\
\text { meeting } \\
\text { (monthly, etc) }\end{array}$ & $\begin{array}{c}\text { About } 50 \% \\
-75 \% \text { every } \\
\text { meeting } \\
\text { (monthly, etc) }\end{array}$ & $\begin{array}{c}\text { About } 50 \% \\
\text { every meeting } \\
\text { (monthly, etc) }\end{array}$ & $\begin{array}{c}\text { About } 25 \% \\
-50 \% \text { every } \\
\text { meeting } \\
\text { (monthly,etc) } \\
\end{array}$ & \\
\hline \multirow[t]{9}{*}{ Groups } & Village Men & 3 & 3 & 1 & 0 & 7 \\
\hline & Men's Church Group & 4 & 0 & 2 & 0 & 6 \\
\hline & Village Women & 2 & 2 & 3 & 2 & 9 \\
\hline & Women's Church Group & 3 & 1 & 4 & 0 & 8 \\
\hline & Village Youth & 3 & 2 & 2 & 0 & 7 \\
\hline & Church Youth & 2 & 2 & 2 & 1 & 7 \\
\hline & Chiefs Council & 1 & 2 & 4 & 1 & 8 \\
\hline & Village Council & 3 & 3 & 3 & 0 & 9 \\
\hline & Village Development Committee & 3 & 0 & 4 & 0 & 7 \\
\hline Total & & 24 & 15 & 25 & 4 & 68 \\
\hline
\end{tabular}

Table 12 - Number of members attending Village Council meetings

\section{c) Documentation and reporting}

The results on Table 13 show that the general response states that meeting are either documented "all the time" or "most of the time". However almost half of the chief's council and village youth groups interviewed, stated that meetings were either "documented a few times" or "never documented at all".

The village council and its other groupings have documentation of meetings according to more than $50 \%$ of the respondents from both villages. However, when asked where these documents are kept, most of them responded that they have not seen them but the secretary keeps them for safekeeping.

With reference to Table 14, the general response according to a total of $18(26 \%)$ stated that "a financial report does not exist". Almost all that were interviewed from the Chief's Council answered that "financial reports do not exist" and almost 50\% from village development committee, village men and village women groups echoed the same answer. The village council and its other associate groups recorded answers about the financial report dissemination ranging from 13 (19\%) "most of the time", 15 (22\%) "sometimes only", and another 15 (22\%) "a few times only".

\begin{tabular}{|c|c|c|c|c|c|c|c|}
\hline & & \multicolumn{5}{|c|}{ Is there documentation of minutes of meeting } & \multirow[b]{2}{*}{ Total } \\
\hline & & $\begin{array}{c}\text { Minutes } \\
\text { documented } \\
\text { all the time }\end{array}$ & $\begin{array}{l}\text { Minutes } \\
\text { documented } \\
\text { most of the } \\
\text { time }\end{array}$ & $\begin{array}{c}\text { Minutes } \\
\text { documented } \\
\text { sometimes }\end{array}$ & $\begin{array}{c}\text { Minutes } \\
\text { documented } \\
\text { a few times } \\
\text { only }\end{array}$ & $\begin{array}{r}\text { Minutes never } \\
\text { documented }\end{array}$ & \\
\hline \multirow[t]{6}{*}{ Groups } & Village Men & 4 & 0 & 1 & 1 & 1 & 7 \\
\hline & Women's Church Group & 4 & 3 & 0 & 0 & 1 & 8 \\
\hline & Village Youth & 0 & 2 & 1 & 3 & 1 & 7 \\
\hline & Church Youth & 1 & 6 & 0 & 0 & 0 & 7 \\
\hline & Chiefs Council & 0 & 2 & 2 & 1 & 3 & 8 \\
\hline & Village Council & 4 & 5 & 0 & 0 & 0 & 9 \\
\hline
\end{tabular}

Table 13 - The Documentation of Meetings 


\begin{tabular}{|c|c|c|c|c|c|c|c|}
\hline & & \multicolumn{5}{|c|}{ Do you have financial reports and disseminated to all } & \multirow[b]{2}{*}{ Total } \\
\hline & & $\begin{array}{l}\text { Finanacial } \\
\text { report, } \\
\text { disseminated } \\
\text { all the time }\end{array}$ & $\begin{array}{l}\text { Finanacial } \\
\text { report, } \\
\text { disseminated } \\
\text { most of the } \\
\text { time }\end{array}$ & $\begin{array}{c}\text { Financial } \\
\text { report, } \\
\text { disseminated } \\
\text { sometimes } \\
\text { only } \\
\end{array}$ & $\begin{array}{c}\text { Financial } \\
\text { report } \\
\text { disseminated } \\
\text { a few times } \\
\text { only } \\
\end{array}$ & $\begin{array}{c}\text { Financial } \\
\text { report does } \\
\text { not exist }\end{array}$ & \\
\hline \multirow[t]{9}{*}{ Groups } & Village Men & 3 & 1 & 0 & 0 & 3 & 7 \\
\hline & Men's Church Group & 2 & 3 & 0 & 0 & 1 & 6 \\
\hline & Village Women & 0 & 1 & 3 & 2 & 3 & 9 \\
\hline & Women's Church Group & 0 & 3 & 1 & 3 & 1 & 8 \\
\hline & Village Youth & 0 & 0 & 3 & 3 & 1 & 7 \\
\hline & Church Youth & 0 & 1 & 3 & 3 & 0 & 7 \\
\hline & Chiefs Council & 0 & 0 & 0 & 2 & 6 & 8 \\
\hline & Village Council & 2 & 2 & 3 & 2 & 0 & 9 \\
\hline & Village Development Committee & 0 & 2 & 2 & 0 & 3 & 7 \\
\hline Total & & 7 & 13 & 15 & 15 & 18 & 68 \\
\hline
\end{tabular}

Table 14 - Institution/Group Documentation \& Dissemination

\section{d) Management action plans}

The results from correspondence on Table 15 showed that the chief's council does not have a Management Action Plan (MAP), with almost all village youth and village women groups echoing the same. Most of the other group's respondents from both villages answered that although they have their MAP, their tasks and activities were either implemented "most times" of "sometimes". This included the village men and church youth groups that accounted for almost 50\% saying "MAP implemented most times". Village council had MAP with its implementation "sometimes only". About 15 (39\%) respondents from Namada village stated that there was "moderate involvement" from the outsiders in MAP formulation and 10 (33\%) from Navukailagi accounted for "strong involvement from outsiders" for MPA formulation (Table 16).

\begin{tabular}{|c|c|c|c|c|c|c|c|}
\hline & & \multicolumn{5}{|c|}{$\begin{array}{l}\text { Does the institution or committee have a Management Action Plan (MAP) and } \\
\text { implemented? }\end{array}$} & \multirow[b]{2}{*}{ Total } \\
\hline & & $\begin{array}{c}\text { MAP } \\
\text { implemented } \\
\text { all the time }\end{array}$ & $\begin{array}{c}\text { MAP } \\
\text { implemented } \\
\text { most of the } \\
\text { time }\end{array}$ & $\begin{array}{l}\text { MAP followed } \\
\text { sometimes } \\
\text { only }\end{array}$ & $\begin{array}{l}\text { MAP followed } \\
\text { a few times } \\
\text { only }\end{array}$ & $\begin{array}{l}\text { MAP does not } \\
\text { exist }\end{array}$ & \\
\hline \multirow[t]{9}{*}{ Groups } & Village Men & 4 & 1 & 1 & 0 & 1 & 7 \\
\hline & Men's Church Group & 1 & 2 & 2 & 0 & 1 & 6 \\
\hline & Village Women & 0 & 2 & 3 & 0 & 4 & 9 \\
\hline & Women's Church Group & 1 & 3 & 3 & 0 & 1 & 8 \\
\hline & Village Youth & 0 & 0 & 0 & 2 & 5 & 7 \\
\hline & Church Youth & 0 & 5 & 2 & 0 & 0 & 7 \\
\hline & Chiefs Council & 0 & 0 & 0 & 0 & 8 & 8 \\
\hline & Village Council & 0 & 4 & 5 & 0 & 0 & 9 \\
\hline & Village Development Committee & 0 & 1 & 6 & 0 & 0 & 7 \\
\hline Total & & 6 & 18 & 22 & 2 & 20 & 68 \\
\hline
\end{tabular}

Table 15 - Institution/Groups Management Action Plans (MAP) 


\begin{tabular}{|c|c|c|c|c|c|c|c|}
\hline & & \multicolumn{5}{|c|}{$\begin{array}{l}\text { Is there collaboration of 'outsiders' with villagers in the formulation and } \\
\text { implementation of Management Action Plans (MAP) }\end{array}$} & \multirow[b]{2}{*}{ Total } \\
\hline & & $\begin{array}{c}\text { Absolute } \\
\text { involvement of } \\
\text { outsiders }\end{array}$ & $\begin{array}{c}\text { Strong } \\
\text { involvement } \\
\text { from } \\
\text { outsiders }\end{array}$ & $\begin{array}{c}\text { Moderate } \\
\text { involvement } \\
\text { from } \\
\text { outsiders }\end{array}$ & $\begin{array}{l}\text { Limited } \\
\text { involvement } \\
\text { from } \\
\text { outsiders }\end{array}$ & $\begin{array}{c}\text { No } \\
\text { involvement } \\
\text { from } \\
\text { outsiders }\end{array}$ & \\
\hline \multirow[t]{2}{*}{ Village } & Namada & 3 & 5 & 15 & 8 & 7 & 38 \\
\hline & Navukailagi & 5 & 10 & 9 & 0 & 6 & 30 \\
\hline Total & & 8 & 15 & 24 & 8 & 13 & 68 \\
\hline
\end{tabular}

Table 16 - Collaboration of 'outsiders' in Management Action Plan formulation

\section{e) Inventory of resources, equipment and facilities}

As shown on Table 17, 41 (60\%) respondents from both villages stated that there were "no" inventory, resources, equipment or facilities to aid the daily functions of their institutions or groups. The remaining 27 (40\%) who responded "yes" had listed church buildings, community hall and furniture as the only inventory of resources they have. For natural resource management activities (e.g. MPA) all they have simple measuring tools and colored floating balls to mark MPA boundary. Villagers from both villages depend on their own working tools like spades, knives and digging forks to do community work as required by the village council.

Count

\begin{tabular}{|c|c|c|c|c|}
\hline & & \multicolumn{2}{|c|}{$\begin{array}{l}\text { Do you have inventory of } \\
\text { resources and } \\
\text { equipment/facilities? }\end{array}$} & \multirow[b]{2}{*}{ Total } \\
\hline & & yes & No & \\
\hline \multirow[t]{9}{*}{ Groups } & Village Men & 4 & 3 & 7 \\
\hline & Men's Church Group & $\mathrm{O}$ & 6 & 6 \\
\hline & Village Women & 6 & 3 & 9 \\
\hline & Women's Church Group & 6 & 2 & 8 \\
\hline & Village Youth & $\mathrm{O}$ & 7 & 7 \\
\hline & Church Youth & 2 & 5 & 7 \\
\hline & Chiefs Council & $\mathrm{O}$ & 8 & 8 \\
\hline & Village Council & 5 & 4 & 9 \\
\hline & Village Development Committee & 4 & 3 & 7 \\
\hline Total & & 27 & 41 & 68 \\
\hline
\end{tabular}

Table 17 - Inventory of Resources, Equipment or Facilities

\section{f) Rules and regulations}

In Table 18, it shows a total of 21 (31\%) respondents from both villages with "no members aware of rules", this sentiments shared mostly by village men, village women and village youth groups. The answer, "Some members are aware of rules" were shared by $19(28 \%)$ respondents of all groups and another $10(14 \%)$ respondents mostly from village council had "most members aware of rules" as their response. Mostly men's church group answered that "all members are aware of rules". 


\begin{tabular}{|c|c|c|c|c|c|c|c|}
\hline & & \multicolumn{5}{|c|}{$\begin{array}{l}\text { Are the members aware of rules and regulations, by-laws to govern the work of the } \\
\text { institution or committee? }\end{array}$} & \multirow[b]{2}{*}{ Total } \\
\hline & & $\begin{array}{c}\text { All the } \\
\text { members are } \\
\text { aware of rules }\end{array}$ & $\begin{array}{l}\text { Most } \\
\text { members are } \\
\text { aware of rules }\end{array}$ & $\begin{array}{c}\text { Some } \\
\text { members are } \\
\text { aware of the } \\
\text { rules }\end{array}$ & $\begin{array}{c}\text { A few } \\
\text { members are } \\
\text { aware of the } \\
\text { rules }\end{array}$ & $\begin{array}{c}\text { No members } \\
\text { aware of the } \\
\text { rules }\end{array}$ & \\
\hline \multirow[t]{6}{*}{ Groups } & Village Men & 1 & 0 & 1 & 0 & 5 & 7 \\
\hline & Village Women & 0 & 0 & 3 & 2 & 4 & 9 \\
\hline & Women's Church Group & 3 & 0 & 3 & 0 & 2 & 8 \\
\hline & Village Youth & 0 & 0 & 2 & 1 & 4 & 7 \\
\hline & Church Youth & 1 & 3 & 2 & 1 & 0 & 7 \\
\hline & Chiefs Council & 0 & 0 & 2 & 4 & 2 & 8 \\
\hline
\end{tabular}

Table 18 - Members Awareness of Rules and Regulations

\section{g) Decision-making (processes and procedures)}

The findings in Table 19 show that 28 (41\%) respondents stated process and procedures were "mostly clear". This was echoed mostly by the village council, village development committee and church youth group. A total of $20(29 \%)$ respondents stated that "it" was "sometimes clear" and was mainly made up of village women group, women's church group and the chief's council.

\begin{tabular}{|c|c|c|c|c|c|c|c|}
\hline & & \multicolumn{5}{|c|}{$\begin{array}{l}\text { Are there clearly defined processes and procedures in place in terms of decision- } \\
\text { making? }\end{array}$} & \multirow[b]{2}{*}{ Tota } \\
\hline & & $\begin{array}{l}\text { Processes } \\
\quad \text { and } \\
\text { procedures } \\
\text { always clear }\end{array}$ & $\begin{array}{l}\text { Processes } \\
\quad \text { and } \\
\text { procedures } \\
\text { mostly clear }\end{array}$ & $\begin{array}{c}\text { Processes } \\
\text { and } \\
\text { procedures } \\
\text { sometimes } \\
\text { clear }\end{array}$ & $\begin{array}{c}\text { Processes } \\
\text { and } \\
\text { procedures is } \\
\text { never clear }\end{array}$ & $\begin{array}{c}\text { Processes } \\
\text { and } \\
\text { procedures } \\
\text { do not exist }\end{array}$ & \\
\hline \multirow[t]{9}{*}{ Groups } & Village Men & 2 & 0 & 2 & 0 & 3 & 7 \\
\hline & Men's Church Group & 1 & 2 & 3 & 0 & 0 & 6 \\
\hline & Village Women & 0 & 4 & 5 & 0 & 0 & 9 \\
\hline & Women's Church Group & 4 & 0 & 4 & 0 & 0 & 8 \\
\hline & Village Youth & 3 & 2 & 1 & 1 & 0 & 7 \\
\hline & Church Youth & 0 & 6 & 1 & 0 & 0 & 7 \\
\hline & Chiefs Council & 0 & 3 & 4 & 1 & 0 & 8 \\
\hline & Village Council & 3 & 6 & 0 & 0 & 0 & 9 \\
\hline & Village Development Committee & 1 & 5 & 0 & 1 & 0 & 7 \\
\hline Total & & 14 & 28 & 20 & 3 & 3 & 68 \\
\hline
\end{tabular}

Table 19 - Decision-making Processes and Procedures

\section{h) Leadership}

The leader of the village council (village spokesperson) is appointed by the village council on the approval of the chief's council. Is a recognized position by the government through the Fijian Affairs Board (FAB). The FAB works through its provincial council (bose ni yasana); district (bose ni tikina) and village council (bose vakoro). However, the traditional leadership is hereditary and follows chiefly lineage. The chief's council deliberates on the rightful title holders before being traditionally installed. According to the finding shown on Table 20, all respondents from both villages stated that tribal chiefs have not been traditionally installed. 
Count

\begin{tabular}{|c|c|c|c|}
\hline & \multirow[t]{2}{*}{$\begin{array}{c}\text { Have tribal } \\
\text { chiefs been } \\
\text { traditonally } \\
\text { installed? } \\
\text { No }\end{array}$} & \multirow[b]{2}{*}{ Total } \\
\hline & & & \\
\hline Groups & Village Men & 7 & 7 \\
\hline & Men's Church Group & 6 & 6 \\
\hline & Village Women & 9 & 9 \\
\hline & Women's Church Group & 8 & 8 \\
\hline & Village Youth & 7 & 7 \\
\hline & Church Youth & 7 & 7 \\
\hline & Chiefs Council & 8 & 8 \\
\hline & Village Council & 9 & 9 \\
\hline & Village Development Committee & 7 & 7 \\
\hline Total & & 68 & 68 \\
\hline
\end{tabular}

Table 20 - Installation of Tribal Leaders

Furthermore, Table 21 show that 44 (65\%) of all respondents have attended some form of leadership and managements training provided by either the Institute of Applied Science (IAS), Ministry of Forestry or the Ministry of Health. All except the village men group have had 3-4 of these trainings already. As highlighted on Table 22, 31 (46\%) of the total respondents shared that 'chief had a fair degree of influence' and this were mostly answers from village youths, chief's council and the village council. Another 24 (35\%) shared that 'chiefs had minimal degree of influence', this answer are mainly from villages women, church groups and the village development committee.

\begin{tabular}{|c|c|c|c|c|c|}
\hline & & \multicolumn{3}{|c|}{$\begin{array}{l}\text { Have the chief and leaders of clans, sub-clans } \\
\text { and various committees attended any leadership } \\
\text { or management training? }\end{array}$} & \multirow[b]{2}{*}{ Total } \\
\hline & & $\begin{array}{l}1-2 \text { training } \\
\text { for leaders } \\
\text { done }\end{array}$ & $\begin{array}{l}\text { 3-4 training } \\
\text { for leaders } \\
\text { done }\end{array}$ & $\begin{array}{l}1-2 \text { training } \\
\text { for leaders } \\
\text { done }\end{array}$ & \\
\hline \multirow[t]{9}{*}{ Groups } & Village Men & 4 & 2 & 1 & 7 \\
\hline & Men's Church Group & 3 & 3 & 0 & 6 \\
\hline & Village Women & 2 & 6 & 1 & 9 \\
\hline & Women's Church Group & 2 & 4 & 2 & 8 \\
\hline & Village Youth & 0 & 3 & 4 & 7 \\
\hline & Church Youth & 0 & 5 & 2 & 7 \\
\hline & Chiefs Council & 0 & 7 & 1 & 8 \\
\hline & Village Council & 0 & 9 & 0 & 9 \\
\hline & Village Development Committee & 2 & 5 & 0 & 7 \\
\hline Total & & 13 & 44 & 11 & 68 \\
\hline
\end{tabular}

Table 21 - Leadership trainings for chief's and leaders

\begin{tabular}{|c|c|c|c|c|c|c|}
\hline & & \multicolumn{4}{|c|}{ Degree of influence of chief in village } & \multirow[b]{2}{*}{ Total } \\
\hline & & $\begin{array}{c}\text { Chief } \\
\text { significantly } \\
\text { and } \\
\text { consistenly } \\
\text { influences } \\
\text { villagers }\end{array}$ & $\begin{array}{l}\text { Chief has a } \\
\text { large degree } \\
\text { of influence }\end{array}$ & $\begin{array}{l}\text { Chief has a } \\
\text { fair degree of } \\
\text { influence }\end{array}$ & $\begin{array}{l}\text { Chief has } \\
\text { minimal } \\
\text { influence }\end{array}$ & \\
\hline \multirow[t]{9}{*}{ Groups } & Village Men & 3 & 0 & 2 & 2 & 7 \\
\hline & Men's Church Group & 0 & 1 & 2 & 3 & 6 \\
\hline & Village Women & 0 & 0 & 3 & 6 & 9 \\
\hline & Women's Church Group & 0 & 0 & 3 & 5 & 8 \\
\hline & Village Youth & 0 & 0 & 7 & 0 & 7 \\
\hline & Church Youth & 1 & 3 & 3 & 0 & 7 \\
\hline & Chiefs Council & 2 & 1 & 5 & 0 & 8 \\
\hline & Village Council & 0 & 1 & 4 & 4 & 9 \\
\hline & Village Development Committee & 0 & 1 & 2 & 4 & 7 \\
\hline Total & & 6 & 7 & 31 & 24 & 68 \\
\hline
\end{tabular}

Table 22 - Degree of Influence of Chief 


\section{i) Connectivity - Work of the natural resource management}

With reference to Table 23 , the general response (41\%) showed that they have an environment committee (so-called natural resources management committee) that is "functional most times" that shares its functions with the village development committee. This was shared by mostly respondents from Namada. Almost respondents from Navukailagi said that although they had a committee looking after their Natural Research Management (NRM), it functioned "sometimes" or "a few times".

Village * Do you have a NRM or EC Committee? Crosstabulation

\begin{tabular}{|c|c|c|c|c|c|c|}
\hline & & \multicolumn{4}{|c|}{ Do you have a NRM or EC Committee? } & \multirow[b]{2}{*}{ Total } \\
\hline & & $\begin{array}{c}\text { There is a } \\
\text { committee } \\
\text { functional all } \\
\text { the time }\end{array}$ & $\begin{array}{l}\text { There is a } \\
\text { committee } \\
\text { functional at } \\
\text { most times }\end{array}$ & $\begin{array}{l}\text { There is a } \\
\text { committee, } \\
\text { functional } \\
\text { sometimes } \\
\text { only }\end{array}$ & $\begin{array}{l}\text { There ia a } \\
\text { committee, } \\
\text { functional a } \\
\text { few times }\end{array}$ & \\
\hline \multirow[t]{2}{*}{ Village } & Namada & 8 & 27 & 3 & 0 & 38 \\
\hline & Navukailagi & 0 & 1 & 13 & 16 & 30 \\
\hline Total & & 8 & 28 & 16 & 16 & 68 \\
\hline
\end{tabular}

Table 23 - Environment or Natural Resources Management Committee

All respondents from both villages agreed that they were aware of NRM stakeholders and government agencies, including NGOs that visited them but only if they were asked to do so.

\subsection{Discussion}

The dual system of contemporary and traditional governance at village level although seem well established is very complex. Traditionally, a Fijian is born into a family with traditional roles and responsibilities. For instance, if one is born in the chiefly family he remains to play roles expected by the chiefly clan. Likewise a traditional chief's spokesperson (matanivanua) can never be raised in position into chiefly status; he and his clan remain matanivanuas as the hereditary role expects them to fulfill. However, in cases where a matanivanua clan member or other traditional role holder is well educated and has skills identified of him, he can be appointed as the leader of the environment committee as in the case of Navukailagi village. However "decision-making" as part of his leadership roles in this contemporary committee is often challenged by others, mostly the chiefly clans in the chief's council. This is an example where overlapping of decision-making processes has created a lot of confusion for villagers. Respondents from interviews even commented on the lack of coordination between the two systems thus reaching a consensus have sometimes become a lengthy and difficult process. One respondent echoes "this is the reality here, which is why our projects like MPA do not come into fulfilment". 
Although the decision making processes and procedures are in place they are not effectively followed. For instances when there is a ban imposed by the village development committee on the Marine Protected Area (MPA), the chief because he has the ultimate authority gives his permission without consultations with the committee responsible for the MPA project. Observations from 'Village Governance' workshops conducted in other villages in Fiji, points to the same problem but general comment is usually "it depends on the type of traditional leaders we have, and those that are educated, spiritually-filled and open-minded usually respects and considers all our roles as equally important for the development and well-being of our village". There were a few respondents sharing sentiments of lack of faith and trust for chiefs caused by the clashes and misunderstanding of the dual system of governance.

Governance allows the groups to articulate their interests and exercising their rights and obligation (UNDP, 2005). The Fijian Affairs Regulation of 1996 makes provision for village councils to make village by-laws which exists in most Fijian villages including Namada and Navukailagi villages. Most village by-laws have been drawn up placing importance on respect for traditional dressing codes, cultural norms and protocols. As part of the by-laws they have formulated culturally accepted strategies when rules are not adhered to. Unfortunately by law these by-laws are not legally recognized as they are not published by government. Although when outside village boundaries villagers are entitled to their individual right, this is not so in the confinements of the village. The misunderstanding and misinterpretation of the customary rights and individual rights causes a lot of confusion. Compliance and enforcement to village rules and natural resource use by-laws are often not adhered to by villagers as a result of these misinterpretations.

The village council is the forum upon which village activities like natural resource management projects are discussed and approved. It is also the only forum where other committees and groups are supposed to voice their opinions freely on matters that concern them. However since chiefs and clan leaders are also part of this forum, often women and youths sit respectfully and understand all that is being discussed. A group of village women respondents stated "our mark of silence is not because we agree with issues being discussed but rather our respect for the chiefs because they have higher authority...sometimes curse can befall us if we don't respect chiefs". According to the UNHabitat, the heart of the concept of governance lay the notion of participation, engagement and inclusion" (UN-Habitat, n.d. p.2). Equity in terms of gender and age are important in membership representation of any community, institution or committee in terms of decision making and societal well-being. The UN-Habitat further adds that bringing a gender perspective to bear on the practice of participation may assist in identifying strategies for amplifying voice and access to decision making of those who tend to be marginalized or excluded by mainstream development initiatives (Conwall, 2003). It ensures that fairness prevails through consensus effort and that solutions or answers shows representation and distribution of the final group decision (Thorndike, 1938).

In the use of good governance and performance indicators to measure performance of decisionmaking institutions the following summary points were deduced from the research:

The social structures found in the two villages' incorporated a dual system where roles and responsibilities overlapped and uncoordinated activities were common. This has caused 
confusion and unattended schedule of activities and meetings by village committees and appointees. Institutional processes and procedures on decision-making are not clearly defined to all members.

- Although the village council allowed for all villagers to participate, the final decisions often rested with the chiefs and clan elders. The church groups in their church monthly meetings discussed and allowed issues raised by women and youths but particular emphasis given on spiritual growth and activities like money collection for church activities but do not include discussions on issues like natural resource management.

- "Human rights" has been highlighted as a stumbling block for current village set-up and one which has been exercised wrongly especially when it has been abused by some people in villages. This often takes place when a village meeting is being convened, some villagers, exercising their human rights, would venture out pursuing their own personal engagements. Respondents highlight the need for intervention by the Fijian Affairs Ministry to discuss this topic with village people so that the traditional leadership structure is not weakened.

- Management Action Plans (MAP) to provide direction for the successful implementation needs collaborative efforts particularly from 'outside' so as to incorporate certain types of management. There is lack of knowledge for formulating management plans to address important issues effectively. Further village action or management plans produce low or negative result as committees cannot organize themselves to attend to identified activities with timelines.

- Villages rarely have the resources and skills to manage their resources completely on their own, even though these communities may at one time have had effective traditional systems to sustain their natural resources. Felt (1990) echoes that transformation to meet modern-day needs, have caused the erosion of the social, economic, and political fundamentals that govern traditional systems hence present-day communities are often less concerned and equipped to conserve their resources.

- Traditional leadership issues, where chiefs or clan leaders have not been traditionally installed, are a major problem. This had led to a fair or lesser degree of influence of the chief on his people. This has a negative bearing on MPA project works.

- Lack of collaborative work with 'outside' actors and stakeholder like government and NonGovernmental Organizations (NGOs).

- Lack of proper documentation of meetings, financial reports, proper documents storage, and their dissemination to all members to ensure transparency and accountability

\section{Recommendations and Solutions}

\subsection{Recommendations for better Governance}

1. The Village Council and its sub-committees, (village organizational/management structures, working partnerships and relationships), must be strengthened with clear work descriptions, activities documentations and periodic updates/reports submission to the stakeholders and members. Despite the high numbers of meetings held in almost all groups in the village council these not result in proper resources or equipment records. Dissemination of meetings minutes is still an issue for its members, when they cannot be present because of their jobs, so they do not have knowledge of the issues discussed. Having documents displayed in community halls in 'notice boards' for all to view could be appropriate to solve this problem. 
2. The chief's council would only be efficient and effective if the traditional leader's position is traditionally recognized by the people they lead. When the membership of traditional institutions is confirmed, the traditional communication network is activated and the Chief establish continuous meeting schedule and tentative agenda. Findings show that most villagers see their chiefs having a fair degree of influence not because he is traditionally installed but because it's a customary practice of respect in their communal living. The Fijian Affairs Board and chief's council should collaboratively work together in this respect, so that major decisions for village projects and natural resource use are not affected.

3. The Village Council has to enforce a Village Management Plan that supports: village economic/infrastructure development; village planning guidelines; financial/resource management; village conservation or rehabilitation resource gathering areas and the promotion of health and better education for children.

4. Maximizing the impacts from church to benefit the people's livelihood for those living in the village or those living abroad, and providing support for their traditional obligations. Natural resource management should be a key agenda in church meetings as most activities of the church are met through sales of these natural resources.

5. Identifying and cultivating relationships with internal and external stakeholders.

6. Resources are supposed to be communally shared but instead the emergence of competiveness to acquiring wealth as an individual is seen to be increasing. This is not a 'good working practice'. The Village trust fund accounts must be established with equally appointed by bearer's office from each clan and gender. Funds use and allocation must be an accountable and transparent process with clear documentation for all to view.

7. Project designs and planning excludes village participation and lacks integration at local level. The absence of proposed schedules of annual activities, in terms of various government ministries visitations resulting in meetings overlap and uncoordinated activities to name a few.

8. Knowledge of traditional natural resource management practices are to be documented to enhance scientific knowledge introduced into village initiatives like MPA. This base information is present, but is lost with the changes in institutions with the elderly and matured village members leaving.

\subsection{Proposal of a Governance Model}

Governance is not really a question of what kind of model is the most appropriate, in some cases the technology cannot simply be imported, but must be adapted to individual circumstances (Dasi, 2006).

The strategy for coherency and collectivism in a village setting may likely lie in village governance model that allows characteristics of good governance principles into both daily operational matters of the dual village system. This model should allow flexibility and respect ethics norms, values, traditional duties or roles, and should consider human rights in terms of allowing representation of gender and age in decision-making. Although this may not be inclusive for the very young members but youths and women's should be equally recognized to express their opinions on matters that concerns their well-being. 
Central to the importance of village well-being is the need to manage resources that provides for their livelihood and sustenance. The village governance model should incorporate elements of governance that is participatory and allows for collectivism in the decisions pertaining to the effective management of resources. The village social structure can be aligned with management practices elsewhere to help streamline and harmonize village activities where all stakeholders take care of their responsibilities in the appropriate timeframe.

The governance model framework (Figure 3) employs the IUCN-WCPA ${ }^{2}$ framework (Lockwood and Kothari, 2006) that recognizes communal settings as in the case of Fiji. The hybrid governance model would be appropriate for communal settings like Fiji coastal villages. The model framework incorporates both traditional ethics and good governance principles to achieve governance quality. It also allows for stakeholders participation within an outside village setting. Clear planning, human inputs and defined processes are important components emphasized. Also key components are outputs and outcomes meaning that the dual systems of governance have a shared but common goal that can only be achieved through collective action. The model also reflects at a local level, elements of collaborative, participative and adaptive governance.

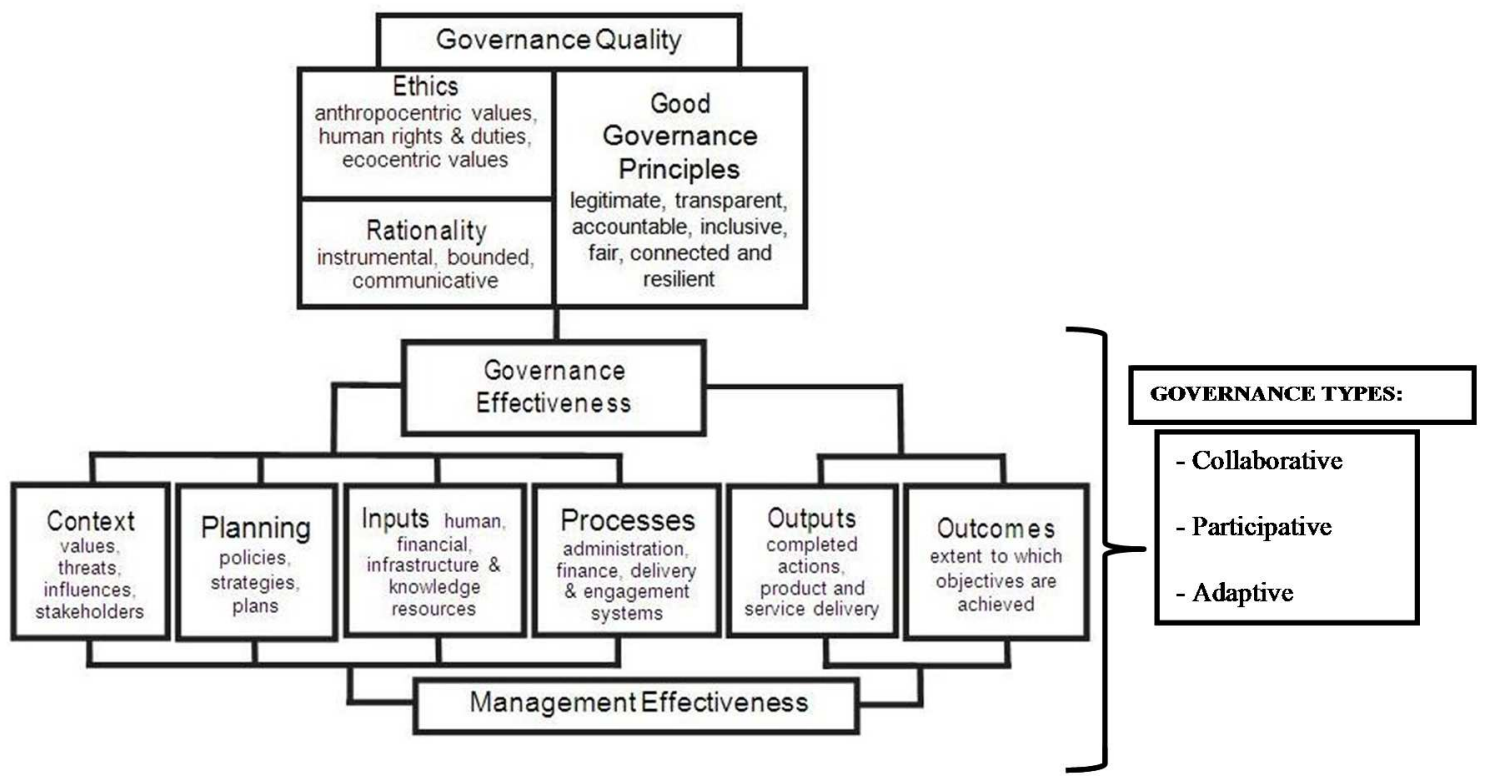

Figure 3 - Proposed governance model framework (Lockwood and Kothari, 2006, p.756)

This proposed governance system is vital as it will consolidate village institutions and their functions. It also ensures the empowerment and protection of village institutions, resource rights, resource rules compliance and enforcement of resource users. In addition to this, cultural values and beliefs regarding coastal resources, leadership and resource conflict between users of marine resources within a village setting is also be addressed.

\footnotetext{
${ }^{2}$ International Union for Conservation of Nature - World Commission on Protected Areas
} 
This model that can be translated as "village governance model" can also strengthen and enhance dynamic relationships at village level and teaches people skills and knowledge of accountability and transparency. It is important that the communities are able to participate in discussions, core roles and functions are defined, positions within the social structure are confirmed, communication links between traditional and contemporary village institutions and subgroups are better defined.

There is a vital need for a smooth networking and integration between the Chief's council, village council, church and stakeholders from governmental and NGOs, so that community would be better able to perform their tasks. With the governance practice in place, this can be then translated into managements of the natural resources not only to provide their daily livelihoods but for its sustainability.

\section{Conclusion}

The dual system of governance in the Fijian village setting has continued to be a problem that has hindered and affected implementation of projects including natural resources management initiative. Resource dependence is vital for the well-being of coastal villages and their sustenance in the long run.

Although Government, NGOs and various stakeholders and actors have pitched in to help with management efforts the problems arising from the dual system at village level have continued to persist. The hybrid governance model with clear processes in place would hope to unify and consolidate institutions so that all management efforts at village level will succeed.

The effectiveness of the community initiative is dependent on the involvement of the whole community concerned, as they are the ones who need to determine the activities they undertake. The traditional unit is useful in this respect because at this level, effective action is dependent on the members observing the rulings and decisions of the group. However, with good governance principles implemented in all spheres of village function and activities this should allow for women and youths to be empowered to decide on issues and concerns that regard their well-being. Leaders also lead with an open-mind knowing that all are equal and that the village wealth or the natural resources belongs to all. Natural resource use and proceeds in terms of royalties or sale is accounted for and being made transparent to all village members.

Village by-laws need to be legally recognized and if possible enshrined in the Fijian Affairs Act, Fisheries Act and Environment Act to enforce village planning and best resource management practices within the village perimeter.

With the hybrid model of governance, clear processes and procedures also enacted in the national framework, implemented and monitored, we would hope to one day see our coastal village people smiling, in peaceful co-existence with natural resources and 'mana' (traditional blessings) be restored. 


\section{References}

CHHOTRAY, V. and STOKER, G. Governance Theory and Practice - A Cross-Disciplinary Approach. Hampshire: Palgrave Macmillanm. 2009.

COCKS, M. Biocultural diversity: moving beyond the realm of 'indigenous' and 'local' people. Human Ecology, 2006, Vol. 34(2), p. 185-200.

DASI, F. ESPON Project 2.3.2: Governance of Territorial and Urban Policies from EU to Local Level. "Final Report", 2006, Luxembourg , Esch-sur-Alzette: ESPON Coordination Unit.

GLESNE, C. \& PESHKIN, A. Becoming qualitative researchers: An introduction. New York: Longman. 1992.

GRAHAM, J., AMOS, B. and PLUMPTRE, T. Principles of Good Governance in the 21st Century. Ontario: Institute of Governance. 2003.

KAMBERELIS, G. and DIMITRIAS, G. Focus groups: Strategic articulations of pedagogy, politics and inquiry. In: N. Denzin and Y. Lincoln, eds. The sage handbook of qualitative research 3rd Edition. Berverly Hills: Sage, 2005. p. 807-907.

KAUFMANN, D., KRAAY, A. and MASTRUZZI, M. Governance Mattets VII: aggregate and individual governance indicators 1996-2008. World Bank. 2009.

KENDI, S. \& GURI, B. Indigenous institutions, governance and development: community mobilization and natural resources in Ghana. Endogenous development and bio-cultural diversity: the interplay between worldviews, globalization and locality. Compas Series on Worldviews and Sciences, 2007, Vol. 6, p. 332-349.

LIJPHART, A. Democracies: Patterns of Majoritarian and Consensus Government in 21 Countries. London: Yale University Press. 1984.

LOCKWOOD, M. Good governance for terrestrial protected areas: A framework, principles and performance outcome. Journal of Environmental Management, 2010, Vol. 91, p. 754-766.

LOCKWOOD, M. and KOTHARI, A. In: Managing Protected Areas. London: Earthscan. 2006, p. 41-72.

MCKENNA, S., IWASAKI, P., STEWARD, T. and MAINS, D. Key informants and community-based participatory research: one is not like the other. Denver: University of Colarado Denver. 2011.

OTSUKA, S. Talanoa Research: Culturally Appropriate Research Design in Fiji. Sydney: University of Sydney. 2006.

PERNETTA, J. and HUGHES, P. Implications of Expected Climate Change in the South Pacific Region: An Overview. UNEP Regional Seas Reports and Studies No.128. Nairobi: United Nations Environment Programme. 1990.

SANDAY, R. Good Governance the Key to Sustainable Development. Suva: SOPAC. 2003.

TAGIVAKATINI, S. J. Village governance in relation to coastal resource management in Fiji: a case study of Namada and Navukailagi villages. Dissertação de Mestrado em Riscos, Cidades e Ordenamento do Território. FLUP. 2013. Disponível em: https://repositorio-aberto.up.pt/bitstream/10216/75830/2/72250.pdf

UNDP. Framework for Piloting-Project on Pro-poor Gender sensitive -Governance Indicators Policing Reform. New York: United Nations. 2005.

UNESCAP. What is Good Governance? Poverty and Devlopment Division. New York: United Nations. 2007.

VAIOLETI, T., Talanoa Research Methodolgy: a developing position on Pacific research. Waikato Journal of Education, 2006, Vol. 12, p. 21-36.

WORLD BANK. Reforming Public Institutions and Strengthening Governance - A world Bank Strategy. Washington, D.C: The World Bank. 2000. 